\title{
Penguatan Konsep Operasi Bilangan Bulat Pada Siswa Inklusi Melalui Media Matryk (Math Story Book)
}

\author{
Rina Rusdiana1, Seroja Miftahul Jannah, Vina Erni Pratiwi, Sandha Soemantri \\ Universitas Muhammadiyah Surabaya \\ e-mail:1rinarusdiana793@gmail.com
}

\begin{abstract}
Abstrak
Meningkatkatnya jumlah Anak Berkebutuhan Khusus di Indonesia setiap tahunnya membuat pihak pemerintah harus melakukan penanganan bagi ABK khususnya dalam bidang pendididikan. Pihak pemerintah telah berusaha untuk memfasilitasi kebutuhan pendidikan bagi ABK dengan adanya Sekolah Luar Biasa. Namun realitasnya SLB kurang maksimal dalam memberikan pelayanan pendidikan terhadap anak didiknya, karena media yang digunakan hampir seluruh SLB di Indonesia masih berbentuk konvensional. Padahal dalam sebuah pembelajaran perlu adanya inovasi pembelajaran supaya peserta didik lebih bersemangat dan mudah memahami materi yang diajarkan, terutama dalam pelajaran matematika karena selama ini matematika masih menjadi pelajaran yang sulit dan tidak digemari siswa. Padahal anak ABK juga memerlukan matematika agar mampu berpikir secara matematis dalam kehidupan sehari-hari. Salah satu upaya memperbaiki media pembelajaran dalam mata pelajaran matematika adalah dengan adanya inovasi media pembelajaran. Pembelajaran matematika untuk ABK dengan media visual 3 dimensi akan sangat menyenangkan dan diminati ABK. Adapun masyarakat sasaran dari program ini adalah siswa kelas I-V SDLB/C KUMARA II SURABAYA. Sebagian besar siswa merasa bosan bahkan tidak mampu memahami matematika dalam proses pembelajaran karena penggunaan media pembelajaran yang masih konvensional. Selain itu, data kuisioner media pembelajaran konvensional vs inovasi media pembelajaran menunjukkan bahwa sebagian besar siswa kelas I-V SDLB/C KUMARA II SURABAYA lebih suka bermain sendiri atau keluar kelas daripada harus memperhatikan guru mengajar. Memperhatikan permasalahan yang ada, dilakukan program pengabdian kepada masyarakat MATRYK (Math Story Book) sebagai upaya dalam inovasi media pembelajaran melalui proses pembelajaran matematika di SDLB/C KUMARA II SURABAYA. Tujuan dari program ini adalah untuk membantu ABK memahami matematika dengan mudah melalui proses pembelajaran matematika dengan langsung mengaplikasikan matematika dalam cerita yang ada di buku sehingga dapat melatih siswa dalam mengatasi persoalan matematika sehingga dapat melatih kemampuan matematis anak sebagai bekal dalam kehidupan sehari-hari.
\end{abstract}

Kata kunci: matryk, matematika, inovasi pembelajaran, tunagrahita

\section{PENDAHULUAN}

Peningkatan jumlah Anak

Berkebutuhan Khusus (ABK) di Indonesia

dari tahun ke tahun semakin meningkat.

Berdasarkan data Susenas Triwulan I yang

dipublikasikan Badan Pusat Statistik (BPS) menyatakan sebanyak 9,9 juta anak Indonesia adalah anak berkebutuhan khusus (ABK) dalam kategori penyandang disabilitas (Winarsih dalam Permatasari, 2016). Pusat Data dan Informasi Kementrian Kesehatan RI pada tahun 2014. 
Berdasarkan data Susenas 2012 didapatkan estimasi penduduk Indonesia yang menyandang disabilitas sebesar $2,45 \%$ dan sekitar 39,97\% dari jumlah tersebut mengalami lebih dari satu keterbatasan atau disabilitas (Infodatin dalam Permatasari, 2016). Berikut ini adalah gambar grafik yang memperlihatkan data penyandang disabilitas dari tahun ke tahun:

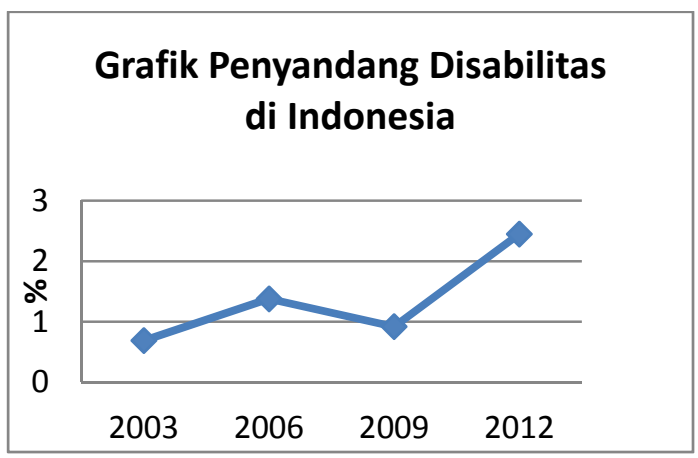

Gambar 1. Grafik penyandang disabilitas di Indonesia

Berkenaan dengan hal tersebut dipandang perlu adanya penanganan khusus bagi anak berkebutuhan khusus terutama dalam bidang pendidikan. Pihak pemerintah sendiri telah berusaha memfasilitasi kebutuhan pendidikan bagi ABK dengan diselenggarakannya Sekolah Luar Biasa (SLB) yang sudah tersebar di seluruh wilayah Indonesia. Tetapi dengan hal tersebut masih terdapat permasalahan dari tiap sekolah bahwa pendidikan anak ABK di Indonesia dipandang masih kurang maksimal sehingga perlu adanya perbaikan.

Menurut buku pedoman
Penyelenggaraan Inklusi Direktorat PSLB
(2004), secara umum program pembelajaran yang disusun oleh guru untuk kelas inklusi sama dengan program pembelajaran pada kelas reguler. Tetapi, kebutuhan dalam kurikulum reguler harus diadaptasi dan dimodifikasi sehingga sesuai dengan kebutuhan anak berkebutuhan khusus.

Modifikasi pembelajaran untuk anak berkebutuhan khusus dapat dilakukan guru pada strategi pembelajaran, jenis penilaian, maupun pada program tambahan lainnya dengan tetap mengacu pada kebutuhan siswa. Penekanan perbaikan terletaj pada taraf kesulitan materi yang disusun dari yang konkret menuju abstrak, dari yang mudah menuju sulit, dan dari sederhana menuju yang kompleks. Oleh karena itu, metode apapun dapat digunakan guru untuk menyampaikan materi dan meningkatkan karakter siswa berkebutuhan khusus (Soemantri, 2019).

Melalui dasar tersebut, hendaknya pendidikan luar biasa mampu memberikan pelayanan pendidikan dengan sebaikbaiknya. Salah satu pelayanan akademik yang diberikan adalah meningkatkan pola pembelajaran pada mata pelajaran matematika karena matematika merupakan ilmu mengenai struktur, pola, hubungan dan aturan-aturan. Selain itu, mata pelajaran matematika adalah satu bidang akademik dasar yang harus diberikan di setiap sekolah. Guru membutuhkan waktu 
dan proses yang bertahap untuk mempersiapkan siswa menguasai matematika. Siswa SLB sangat berbeda dengan siswa pada sekolah formal sehingga membutuhkan perlakuan khusus dalam pembelajaran matematika. Kegiatan belajar mengajar yang berlangsung di SLB meliputi semua aktivitas yang memberikan materi pelajaran kepada siswa agar siswa mempunyai kecakapan dan pengetahuan memadai yang dapat memberikan manfaat bagi perkembangan peserta didik.

Dalam proses belajar mengajar matematika selain melibatkan pendidik atau guru dan siswa secara langsung, juga diperlukan pendukung yang lain yaitu: alat pelajaran yang memadai, penggunaan metode yang tepat, serta situasi dan kondisi lingkungan yang menunjang. Banyak faktor yang mempengaruhi hasil belajar matematika pada siswa SLB. Salah satu faktor yang sangat penting yaitu guru yang mengajar. Faktor guru dan cara mengajar memiliki peranan yang sangat penting dalam meningkatkan prestasi belajar matematika siswa. Bagaimana sikap dan kepribadian guru, tinggi rendahnya pengetahuan yang dimiliki guru, dan bagaimana guru itu mengajarkan pengetahuan itu kepada peserta didiknya, turut menentukan bagaimana hasil belajar yang dapat dicapai peserta didik (Purwanto, 2002).
Pendapat Purwanto tersebut sejalan dengan prinsip-prinsip pendekatan khusus yang dikemukakan oleh Abdullah (dalam Soemantri, 2019). Beberapa prinsip mendidik anak berkebutuhan khusus antara lain sebagai berikut:

1. Prinsip kasih sayang. Pada dasarnya adalah menerima mereka apa adanya. Upaya yang dilakukan antara lain tidak bersikap memanjakan, tidak bersikap acuh tak acuh, dan memberikan tugas yang sesuai dengan kemampuan anak.

2. Prinsip layanan individual. Upaya yang perlu dilakukan antara lain jumlah siswa yang dilayani antara $4-6$ siswa per kelas, kurikulum dan jadwal pelajaran dapat bersifat fleksibel, tata ruang harus dirancang sedemikian rupa sehingga guru dapat menjangkau semua siswa dengan mudah, dan adanya alat bantu pembelajaran.

3. Prinsip kesiapan. Untuk menerima suatu pelajaran tertentu diperlukan kesiapan khususnya kesiapan dalam pengetahuan prasyarat, baik pengetahuan, mental, serta fisik

4. Prinsip keperagaan. Alat peraga yang digunakan untuk media sebaiknya diupayakan menggunakan benda nyata atau yang sesuai dengan situasi aslinya.

5. Prinsip motivasi. Pada dasarnya prinsip motivasi lebih menitikberatkan pada cara mengajar dan pemberian evaluasi yang disesuaikan dengan kondisi anak 
6. Prinsip belajar dan bekerja kelompok. Titik berat dalam hal ini adalah kemampuan anak untuk belajar dan bekerja secara berkelompok, sehingga nantinya dapat bergaul dengan masyarakat di lingkungannya, tanpa harus merasa rendah diri.

7. Prinsip keterampilan. Titik berat pada prinsip ini adalah keterampilan yang berfungsi selektif, edukatif, rekreatif dan terapi, serta dapat dijadikan sebagai bekal dalam kehidupannya kelak.

8. Prinsip penanaman dan penyempurnaan sikap, yang mengharapakan bahwa anak berkebutuhan khusus memiliki sikap yang baik sehingga tidak selalu menjadi perhatian orang lain.

Permasalahan utama di Sekolah Luar Biasa adalah sekolah masih menggunakan media konvensial dalam pembelajaran matematika sehingga siswa kurang tertarik untuk belajar matematika. Hal ini juga terjadi di SDLB/C Kumara II Surabaya. Sehingga dibutuhkan sebuah pembaharuan melalui media yang mampu menarik minat siswa terhadap matematika. Hasil observasi dan pre-test dalam pembelajaran matematika di kelas I-V SDLB/C Kumara II Surabaya, diperoleh bahwa nilai pre-test siswa masih rendah serta kurangnya keaktifan dalam mengikuti pembelajaran matematika.

Berdasarkan masalah di atas, diperlukan inovasi media pembelajaran yang dapat mengatasi masalah tersebut yaitu penerapan media MATRYK dalam pembelajaran matematika. MATRYK adalah media pembelajaran berupa buku cerita yang menggabungkan cerita pada kehidupan sehari-hari dengan pelajaran matematika dasar bagi anak. MATRYK dibuat untuk memudahkan anak berkebutuhan khusus dalam memahami materi matematika karena anak dapat langsung mengaplikasikan matematika dalam cerita yang ada di buku sehingga dapat melatih siswa dalam mengatasi persoalan matematika serta melatih kemampuan matematis anak sebagai bekal dalam kehidupan sehari-hari.

Tujuan dari program ini adalah untuk membantu ABK memahami matematika dengan mudah melalui proses pembelajaran matematika dengan media MATRYK sehingga diharapkan dapat meningkatkan ketertarikan siswa dalam pembelajaran matematika.

\section{TARGET LUARAN}

Target luaran dari pelaksanaan program pengabdian kepada masyarakat diberikan pada Tabel 1.

Tabel 1. Luaran dan Indikator Capaian

\begin{tabular}{|l|l|lr|}
\hline No. & Jenis Luaran & \multicolumn{2}{|l|}{ Indikator Capaian } \\
\hline 1. & Menciptakan & Media MATRYK \\
& suatu media & yang sudah \\
baru yang dapat & diterapkan di \\
& $\begin{array}{l}\text { memudahkan } \\
\text { anak } \\
\text { berkebutuhan } \\
\text { khusus dalam }\end{array}$ & SDLB/C & KUMARA II \\
& \\
\hline
\end{tabular}




\begin{tabular}{|c|c|c|}
\hline & $\begin{array}{l}\text { belajar } \\
\text { matematika }\end{array}$ & \\
\hline 2. & $\begin{array}{l}\text { Penerapan } \\
\text { media } \\
\text { pembelajaran } \\
\text { MATRYK } \\
\text { dalam proses } \\
\text { pembelajaran } \\
\text { matematika } \\
\text { dapat } \\
\text { meningkatkan } \\
\text { kemampuan } \\
\text { kognitif anak } \\
\text { dalam } \\
\text { pembelajaran } \\
\text { matematika. }\end{array}$ & $\begin{array}{ll}\text { Secara } & \text { kognitif } \\
\text { siswa mampu } \\
\text { menyelesaikan } \\
\text { soal operasi } \\
\text { hitung bilangan. } \\
\text { Serta adanya } \\
\text { peningkatan nilai } \\
\text { post-test. }\end{array}$ \\
\hline 3. & $\begin{array}{l}\text { Menciptakan } \\
\text { proses } \\
\text { pembelajaran } \\
\text { yang } \\
\text { menyenangkan } \\
\text { dengan media } \\
\text { pembelajaran } \\
\text { MATRYK. }\end{array}$ & $\begin{array}{l}\text { siswa mampu } \\
\text { menghargai setiap } \\
\text { proses } \\
\text { pembelajaran dan } \\
\text { memahami materi } \\
\text { dengan } \\
\text { mengaplikasikan } \\
\text { secara langsung. }\end{array}$ \\
\hline 4. & $\begin{array}{l}\text { Artikel sebagai } \\
\text { publikasi dari } \\
\text { program yang } \\
\text { telah } \\
\text { dilaksanakan } \\
\text { baik dalam } \\
\text { jurnal } \\
\text { pengabdian } \\
\text { masyarakat } \\
\text { maupun dalam } \\
\text { seminar. }\end{array}$ & $\begin{array}{l}\text { Artikel terbit di } \\
\text { jurnal nasional } \\
\text { ber-ISSN }\end{array}$ \\
\hline 5. & $\begin{array}{l}\text { Buku panduan } \\
\text { media } \\
\text { MATRYK yang } \\
\text { telah ber-ISBN. }\end{array}$ & $\begin{array}{l}\text { Cetak buku } \\
\text { panduan } \\
\text { MATRYK yang } \\
\text { sudah ber-ISBN } \\
\text { dan dibagikan } \\
\text { kepada } \\
\text { masyarakat } \\
\text { sasaran. }\end{array}$ \\
\hline 6. & $\begin{array}{l}\text { HKI produk } \\
\text { media } \\
\text { pembelajaran } \\
\text { MATRYK. }\end{array}$ & \begin{tabular}{l}
\multicolumn{2}{l}{ Mendapatkan } \\
sertifikat HKI \\
buku panduan \\
MATRYK
\end{tabular} \\
\hline
\end{tabular}

\section{METODE PENELITIAN}

Metode pelaksanaan program pengabdian kepada masyarakat MATRYK, terdiri dari beberapa tahapan. Tahapan program yang dilakukan anatara lain:

1) Persiapan Program

Tahap persiapan dalam pelaksanaan program meliputi survei daerah sasaran, serta memohon izin kepada masyarakat sasaran. Perizinan dilakukan kepada kepala sekolah dan guru matematika yang mengampu mata pelajaran matematika di SDLB/C KUMARA II SURABAYA untuk melaksanakan program.

2) Pembuatan Media Pembelajaran MATRYK

Media pembelajaran MATRYK adalah komponen yang paling utama dalam pelaksanaan program ini. Tim pelaksana program membuat media sesuai dengan konsep media yang direncanakan di awal. Media pembelajaran MATRYK ini berupa buku cerita yang didesain secara menarik dan mengandung unsur pembelajaran matematika yang dapat menciptakan pembelajaran matematika yang menyenangkan

3) Penyusunan buku panduan

Tim pelaksana program menyusun buku panduan sebagai pedoman bagi panitia pelaksana program dan peserta program (siswa SDLB/C KUMARA II SURABAYA) dalam menggunakan media MATRYK, buku panduan ini tidak hanya berisi tentang petunjuk penggunaan media MATRYK, tetapi juga dilengkapi dengan materi yang akan dipelajari dengan media MATRYK. 
4) Koordinasi program pada masyarakat sasaran SDLB/C KUMARA II SURABAYA

Tim pelaksanan program melakukan koordinasi dengan pihak SDLB/C KUMARA II SURABAYA terkait jadwal sosialisasi dan implementasi program.

5) Sosialisasi Program

Sosialisasi program dilakukan kepada masyarakat sasaran SDLB/C KUMARA II SURABAYA untuk mengenalkan media MATRYK

6) Implementasi program kepada masyarakat sasaran

Implementasi program dilakukan di SDLB/C KUMARA II SURABAYA pada saat proses pembelajaran matematika. Langkah-langkah pembelajaran dilakukan sesuai dengan yang ada di buku panduan media MATRYK. Implementasi program dilakukan selama 7 kali pertemuan dengan rincian kegiatan sebagai berikut:

- Pertemuan ke-1:

Pada pertemuan pertama kami melakukan observasi pada saat proses pembelajaran matematika yang dilakukan menggunakan media konvensional, setelah itu kami melakukan pre-test untuk mengukur kemampuan siswa sebelum kami beri perlakuan.

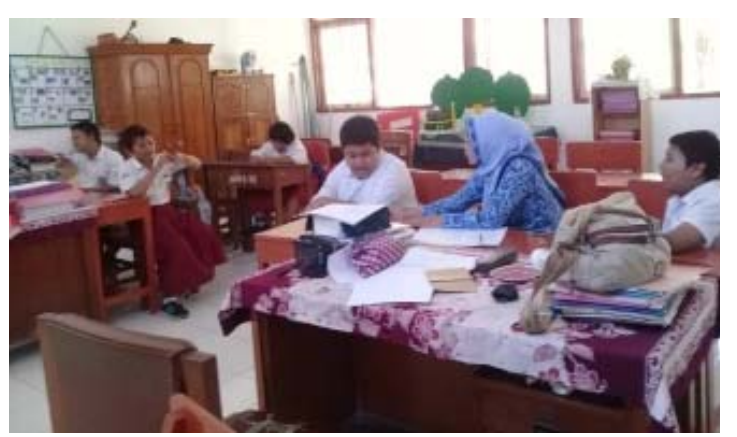

Gambar 1. Pertemuan pertama siswa melakukan Pre-test

- Pertemuan ke-2:

Pada pertemuan kedua kami melakukan pembelajaran menggunakan media MATRYK pada materi penjumlahan.

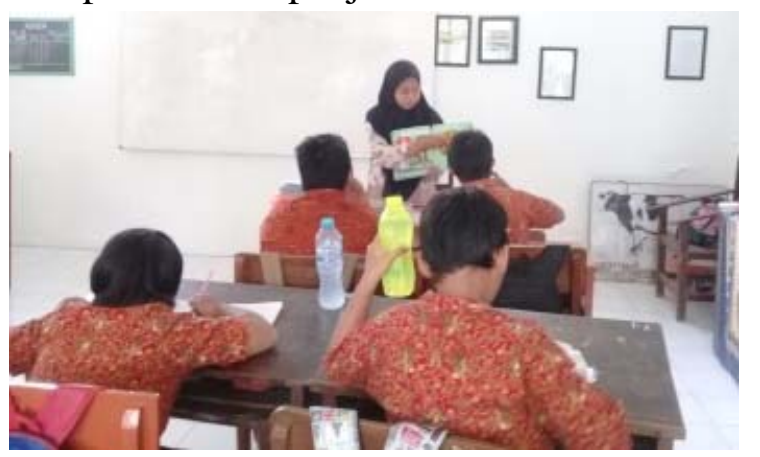

Gambar 2. Pertemuan kedua siswa belajar penjumlahan

- Pertemuan ke-3:

Pada pertemuan ketiga kami melakukan pembelajaran menggunakan media MATRYK pada materi pengurangan.

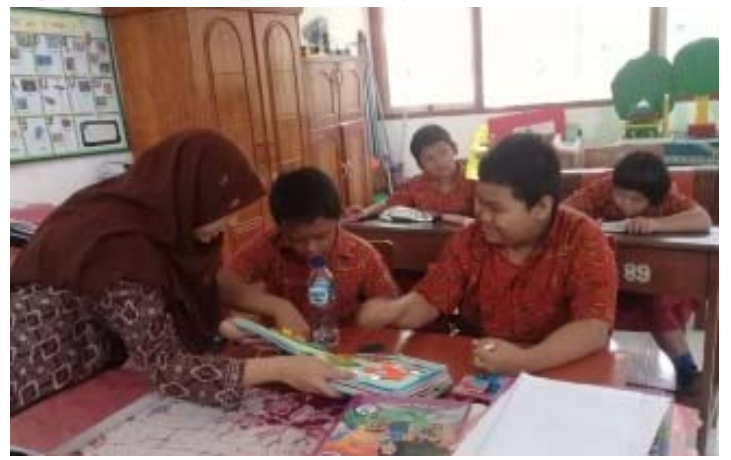

Gambar 3. Pertemuan ketiga siswa belajar pengurangan

- Pertemuan ke-4

Pada pertemuan keempat kami melakukan pembelajaran menggunakan media MATRYK pada materi perkalian 


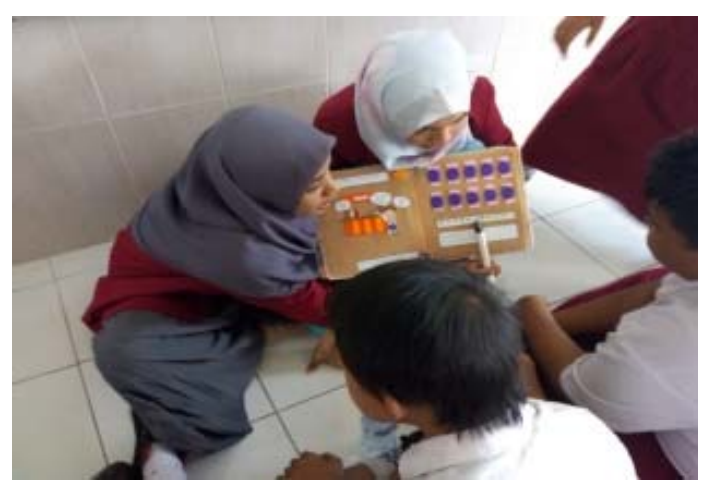

Gambar 4. Pertemuan keempat siswa belajar perkalian

- Pertemuan ke-5

Pada pertemuan kelima kami melakukan pembelajaran menggunakan media MATRYK pada materi perkalian dan pembagian.

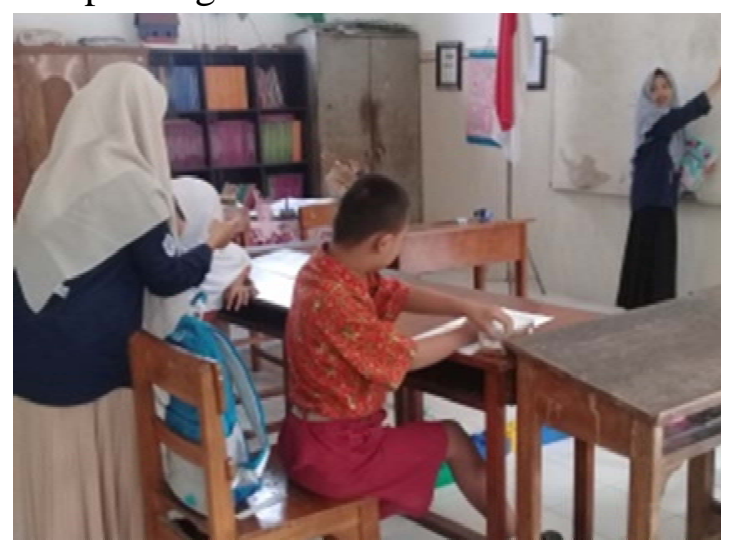

Gambar 5. Pertemuan kelima belajar perkalian dan pembagian

- Pertemuan ke-6

Pada pertemuan keenam kami melakukan pembelajaran menggunakan media MATRYK pada materi operasi hitung pembagian.

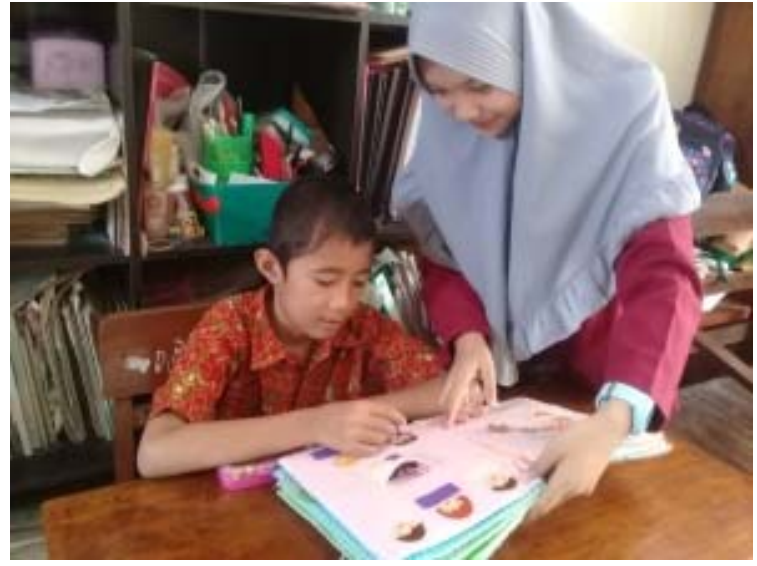

Gambar 6. Pertemuan keenam belajar pembagian

- Pertemuan ke-7

Pada pertemuan ketujuh kami melakukan post-test untuk menguji kemampuan matematika siswa setelah menggunakan media pembelajaran MATRYK. Pada pertemuan ke tujuh ini kami juga melakukan pemilihan siswa terbaik yang akan kami jadikan kader MATRYK. Siswa terbaik kami pilih berdasarkan nilai posttest dan keaktifan siswa selama proses pembelajaran.

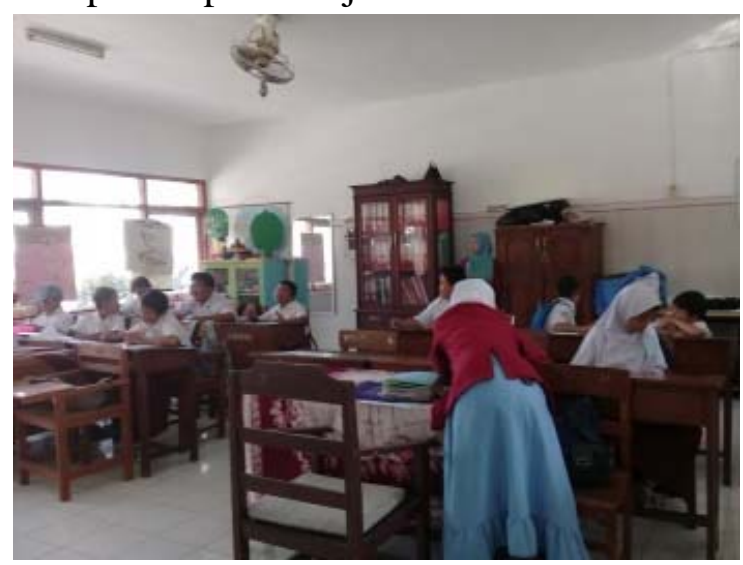

Gambar 7. Pertemuan ketujuh melakukan post-test

7) Pemilihan Kader

Kader dipilih dengan tujuan untuk mengenalkan media pembelajaran MATRYK kepada siswa baru di SDLB/C KUMARA II SURABAYA. Kader dipilih dari siswa terbaik yang 
dipandang aktif dalam proses pembelajaran serta guru matematika.

8) Pengurusan HKI media MATRYK

Tim pelaksana program melakukan pengurusan hak cipta media MATRYK.

9) Evaluasi Program

Evaluasi program dilakukan untuk mengetahui pengaruh penggunaan media terhadap perkembangan kemampuan siswa dalam pembelajaran matematika. Selain itu evaluasi juga dilakukan untuk mengetahui kekurangan dari pelaksanaan program yang telah dilaksanakan sebagai bahan pelajaran dalam melaksanakan program berikutnya.

10) Pembinaan kader MATRYK

Tiga siswa dan satu guru sebagai kader MATRYK akan dibina oleh tim pelaksana program agar menguasai media pembelajaran MATRYK, sehingga mereka dapat meneruskan pengenalan dan implementasi media MATRYK pada para siswa baru.

\section{HASIL DAN PEMBAHASAN}

Program pengabdian masyarakat dengan media MATRYK memiliki hasil capaian sesuai dengan luaran dan tujuan yang tim pelaksana program harapkan. Hasil dari program MATRYK antara lain:

1. Pembuatan media pembelajaran MATRYK

Media pembelajaran MATRYK akan digunakan dalam implementasi program pada masyarakat sasaran. Media MATRYK ini berupa buku cerita yang mengabungkan cerita dengan pelajaran matematika dasar bagi anak seperti operasi bilangan dan bangun ruang. Dengan media pembelajaran MATRYK anak dapat langsung mengaplikasikan matematika dalam cerita yang ada di buku sehingga dapat melatih siswa dalam mengatasi persoalan matematika sehingga dapat melatih kemampuan matematis anak sebagai bekal dalam kehidupan sehari-hari.

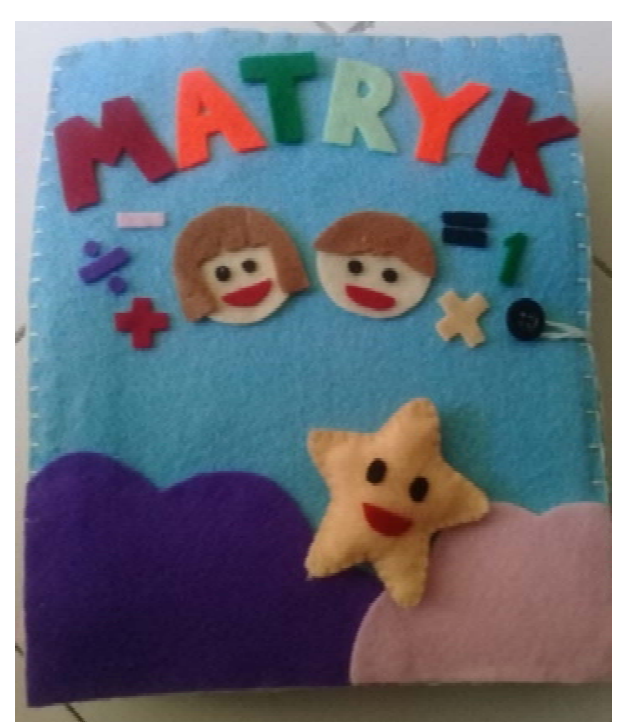

Gambar 8. Media MATRYK

2. Adanya penerapan media MATRYK dalam proses pembelajaran matematika di SDLB/C KUMARA II SURABAYA dapat melatih siswa dalam mengatasi persoalan matematika sehingga dapat meningkatkan kemampuan matematis anak sebagai bekal dalam kehidupan sehari-hari. Hal tersebut ditunjukkan dengan peningkatan nilai siswa pada hasil post-test. Peningkatan nilai siswa ditunjukkan pada grafik berikut ini 


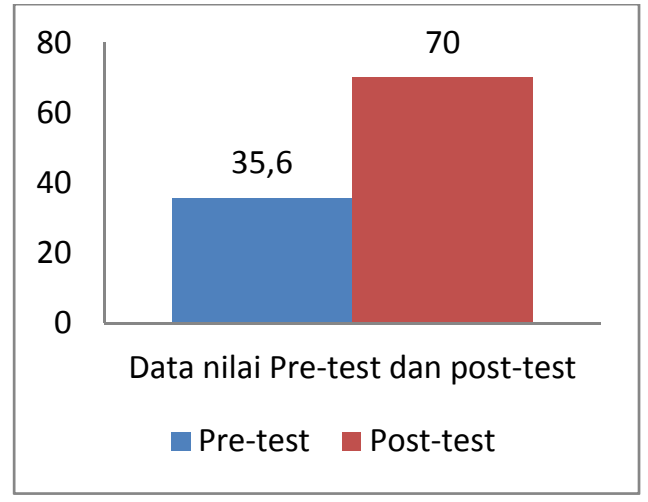

Gambar 9. Data pretest-posttest

3. Menciptakan proses pembelajaran yang menyenangkan dengan media pembelajaran MATRYK yang kami desain dengan karakter dan warnawarna yang menarik sehingga membuat anak merasa senang dan tertarik untuk belajar matematika. Dalam implementasi media MATRYK di SDLB/C KUMARA II SURABAYA, tim pelaksana program melakukan observasi terkait respon dan partisipasi siswa selama pembelajaran menggunakan media MATRYK. Hasil dari observasi yang kami lakukan terhadap 15 siswa ditunjukkan pada grafik berikut ini

\section{Grafik Hasil Observasi}

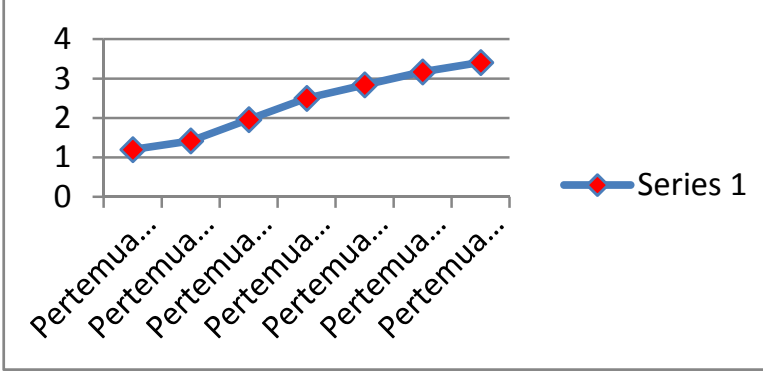

Gambar 10. Grafik hasil observasi

Berdasarkan hasil observasi terdapat peningkatan ketertarikan siswa dalam pembelajaran matematika sehingga dapat disimpulkan bahwa siswa merasa senang dan tertarik dengan pembelajaran menggunakan media MATRYK.

4. Artikel sebagai publikasi dari program yang telah dilaksanakan sedang dalam proses penerbitan di juranal

Selain hasil luaran yang diharapkan dan telah dicapai sesuai dengan proposal, program ini memiliki luaran tambahan yang telah dicapai yaitu:

1. Buku panduan media pembelajaran MATRYK

Tim pelaksana program menyusun buku panduan sebagai pedoman bagi panitia dan peserta program dalam melaksanakan program. Buku panduan sedang dalam pendaftaran ISBN

2. HKI produk media pembelajaran MATRYK

Tim pelaksana program sedang dalam proses mengurus Hak Cipta dari media pembelajaran MATRYK. Proses pembuatan Hak Cipta media dilakukan oleh tim pelaksana program di biro HKI Universitas Muhammadiyah Surabaya.

Program pengabdian kepada masyarakat MATRYK ini juga memiliki potensi hasil serta manfaat yang akan diperoleh oleh tim pelaksana program dan masyarakat. Potensi hasil serta manfaat dari adanya program MATRYK yang telah kami laksanakan ini antara lain:

Berdasarkan pelaksanaan kegiatan pengabdian yang telah dilakukan selama 5 bulan. Potensi hasil yang diperoleh dari 
hasil pelaksanaan kegiatan pengabdian ini adalah sebagai berikut:

1. Manfaat Artikel Ilmiah

Artikel ilmiah terkait program MATRYK ini nantinya dapat menjadi tambahan referensi untuk pembaca atau masyarakat, menambah wawasan serta pengetahuan dalam menggali potensi dan kekayaan intelektual masyarakat untuk mengembangkan suatu inovasi dan ide lain yang bermanfaat bagi kehidupan seharihari. Artikel ilmiah yang sudah dibuat akan dipublikasi dalam jurnal ilmiah maupun berita online

2. HKI

Media MATRYK sudah kami daftarkan di biro HKI Universitas Muhammadiyah Surabaya.

3. Buku Panduan ber ISBN

Buku panduan sedang dalam pendaftaran ISBN. Berikut adalah surat keterangan pengurusan ISBN

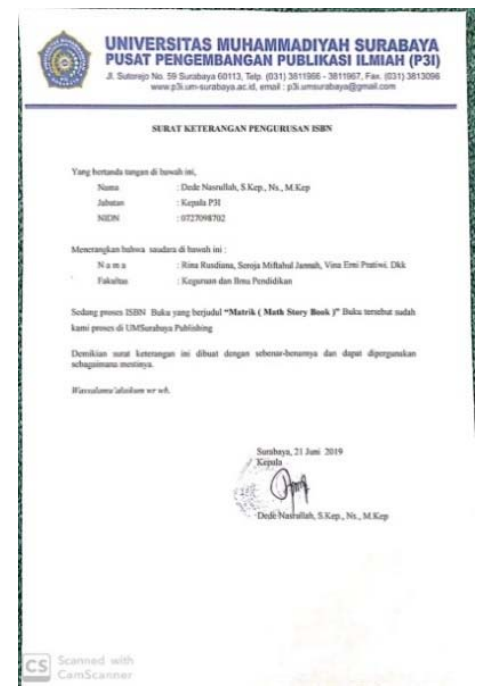

Gambar 11. Surat Keterangan Pengurusan ISBN

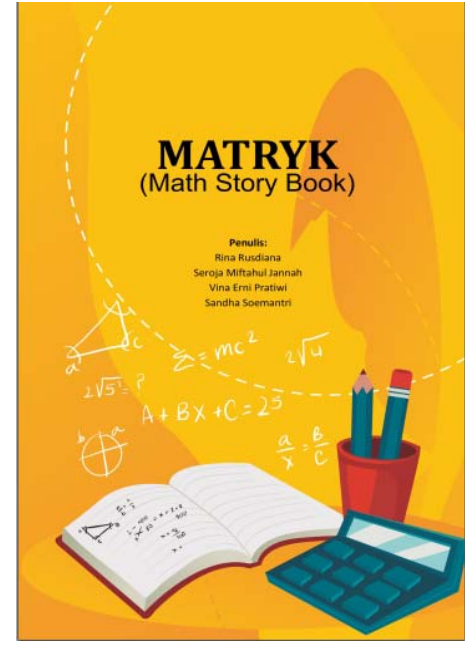

Gambar 12. Buku Panduan

4. Manfaat aspek pendidikan

Pada aspek pendidikan, program pengabdian masyarakat dengan media pembelajaran MATRYK ini memberi sumbangan manfaat berupa: hasil dari program ini adalah suatu mediapembelajaran matematika MATRYK. Adanya penggunaan media pembelajaran

MATRYK diharapkan dapat meningkatkan minat siswa dalam proses pembelajaran matematika. Selain itu, hal ini dapat menjadikan guru untuk lebih aktif berinovasi dalam mengembangkan media pembelajaran lain.

\section{SIMPULAN}

Program pengabdian kepada masyarakat MATRYK telah dilaksanakan dengan baik dan lancar, sesuai tujuan dan luaran yang diharapkan. Pembelajaran matematika dengan inovasi media 
pembelajaran MATRYK ini dapat meningkatkan minat dan kemampuan siswa dalam proses pembelajaran matematika.

\section{DAFTAR PUSTAKA}

Direktorat Pendidikan Luar Biasa. 2004. Pedoman Umum Penyelenggaraan Pendidikan Inklusif. Jakarta: Dirjendikdasmen.

Permatasari, Dwi. 2016. Humanistic Brief Group Therapy untuk Meningkatkan Penerimaan Ibu yang memiliki Anak Cerebral Palsy. http://etd.repository.ugm.ac.id/. (22 mei 2019).

Rozhana, K,M \& Sari, N,K. 2018. Pelaksanaan Pendidikan Karakter dalam Proses Pembelajaran untuk Menumbuhkan Sikap Nasionalisme. Prosiding Seminar Nasional Pengembangan Profesionalisme Dosen dan Guru Indonesia, Volume 2 (Online)

(https://semnas.unikama.ac.id/fip/un duhan/2018/47851298.pdf), di akses 21 Juni 2019.

Sari, NK. 2016. Kemampuan Berpikir Kreatif Konsep Geometri Siswa.
Prosiding Seminar Nasional Pendidikan Matematika. Volume 1 (online)

http://repository.unikama.ac.id/839/1 /PROSIDING\%20SEMINAR\%20N ASIONAL\%20PENDIDIKAN\%20 MATEMATIKA\%202016.pdf, diakses 15 Mei 2019.

Sari, NK. 2016. Menggunakan Penajaman Ciri Questioning \& Clarifying Untuk Membelajarkan Fungsi Polinomial. Jurnal Silogisme: Kajian Ilmu Matematika dan Pembelajarannya Volume 1 No. 2 (online) http://journal.umpo.ac.id/index.php/s ilogisme/article/view/270/258 diakses pada 15 mei 2019.

Soemantri, Sandha. 2019. PBL dengan pendekatan realistic mathematic meningkatkan nilai karakter siswa berkebutuhan khusus. Math Didactic: Jurnal Pendidikan Matematika, Vol. 5 No.1

Tarnoto, Nissa. 2016. PermasalahanPermasalahan yang Dihadapi sekolah Penyelenggara Pendidikan Inklusi pada Tingkat SD. Humanitas, Vol. 13 No. 1 